Dorota Kokowicz

ORCID: 0000-0001-8985-1968

Uniwersytet Wrocławski

https://doi.org/10.19195/1733-5779.38.5

\title{
Marka jako nośnik wizerunku kraju pochodzenia - Rosja w narracji marketingowej Moscow Centre of SPARC Technologies o marce Elbrus
}

Słowa kluczowe: efekt kraju pochodzenia, wizerunek Rosji, marka narodowa, branding narodowy, marki jako kanały komunikowania

Keywords: country-of-origin effect, image of Russia, nation brand, nation branding, brands as communication channels

Abstrakt: Niniejszy artykuł ma na celu ukazanie, w jaki sposób Moscow Centre of SPARC Technologies (MCST) komunikuje o rosyjskiej marce komputera Elbrus i — tym samym — jak marka ta staje się jednocześnie nośnikiem wizerunku kraju swojego pochodzenia - Rosji. Autorka przedstawia wyniki analizy zawartości strony internetowej MCST, aby ukazać, jaki wizerunek Rosji wyłania się z narracji marketingowej o marce, która to narracja jest pełna odwołań do bieżącej sytuacji politycznej tego kraju i jego historii.

\section{The brand as a carrier of the image of its country of origin - Russia in marketing narration of the Moscow Centre of SPARC Technologies about the Elbrus brand}

Abstract: The author of this article demonstrates how the Moscow Centre of SPARC Technologies (MCST) communicates on Russian computer brand Elbrus and the same time how this brand becomes a carrier of image of its country of origin: Russia. The author also presents the results of the content analysis of the MCST's website in order to show what image of Russia emerges from marketing narration about the brand, full of references to current political situation of Russia and its history.

\section{Wstęp}

Dzisiejszy zglobalizowany świat jest wielkim rynkiem, na którym ponad dwieście krajów walczy o uwagę swoich grup docelowych — zagranicznych turystów, 
inwestorów, konsumentów, przedsiębiorców czy studentów ${ }^{1}$. Wyzwania, z którymi współcześnie muszą się zmierzyć kraje, stawiają przed nimi konieczność wykorzystywania narzędzi strategicznego zarządzania marketingowego i podejmowania świadomych działań brandingowych ${ }^{2}$, których głównym celem jest kształtowanie i utrzymanie pozytywnego wizerunku wśród grupy docelowej marki narodowej.

Według Simona Anholta kraje, budując jednocześnie swoją reputację na arenie międzynarodowej, komunikują się poprzez sześć kanałów. Należą do nich turystyka, polityka zagraniczna i wewnętrzna, inwestycje zagraniczne, kultura, ludzie oraz marki, składające się na tożsamość konkurencyjną kraju ${ }^{3}$. Wizerunki krajów tworzone w głowach odbiorców przez marki są jednak stereotypami i kliszami. Jednak wierząc w wizerunki krajów, „wierzymy również, że produkty, które z nich pochodzą, mają takie same przymioty, wady i właściwości”ł.

Celem niniejszego artykułu jest więc ukazanie, które charakterystyczne atrybuty Rosji wykorzystywane są w narracji marketingowej Moscow Centre of SPARC Technologies o rosyjskiej marce komputera Elbrus, a tym samym — jaki wizerunek Rosji się z tej narracji wyłania.

\section{Wizerunek kraju w narracji marketingowej marek — problem efektu kraju pochodzenia}

W przypadku, wspomnianego w kontekście relacji marka-państwo, efektu kraju pochodzenia mamy do czynienia $\mathrm{z}$ efektem halo, kiedy to państwo oddaje swoim markom część swojego wizerunku. Jeśli jest on korzystny, tworzy dla nich korzystny klimat do rozwoju ${ }^{5}$. Spostrzeżenia dotyczące relacji między wizerunkiem kraju a wizerunkami marek z nich pochodzących wskazują więc na możliwość czerpania przez przedsiębiorców i ich marki korzyści, które wynikają z komunikowania przez nich faktu, iż pochodzą z danego kraju. W tym miejscu jednak warto wyjaśnić, czym różnią się pojęcia: tożsamość i wizerunek kraju.

Tożsamość kraju rozumiana jest jako pewien zbiór atrybutów komunikowanych otoczeniu przez kraj, będących przejawem wewnętrznej spójności i umożliwiających wywołanie świadomości odrębności danego kraju ${ }^{6}$. I tak jak tożsamość or-

${ }^{1}$ S. Anholt, Tożsamość konkurencyjna. Nowe spojrzenie na markę, przeł. Instytut Marki Polskiej, Warszawa 2007, s. 7.

$2 \mathrm{Ph}$. Kotler, D. Gertner, Country as a brand, product, and beyond: A place marketing and brand management perspective, „Journal of Brand Management” 9, 2002, nr 4-5, s. 253.

3 S. Anholt, op. cit., s. 39-40.

${ }^{4}$ S. Anholt, Sprawiedliwość marek. Jak branding miejsc i produktów może uczynić kraj bogatym, dumnym i pewnym siebie, przeł. M.A. Boruc, M. Hereźniak, Warszawa 2006, s. 159.

${ }^{5}$ Warto w tym miejscu również wspomnieć, że w procesie brandingu narodowego występuje również zjawisko odwrotne - kiedy to pozytywny wizerunek marki wpływa na pozytywne postrzeganie kraju jej pochodzenia (efekt sumaryczny).

${ }^{6}$ M. Ryniejska-Kiełdanowicz, Public relations Polski w okresie kandydowania do Unii Europejskiej, Wrocław 2007, s. 52-53. 
ganizacji jest przejawem tego, że organizacja jest świadoma swojej pozycji rynkowej oraz sposobów jej identyfikacji, tak i tożsamość państwa będzie oznaczać świadomą autoprezentację kraju zarówno wewnątrz, jak i na zewnątrz.

Według Dariusza Tworzydły na tożsamość organizacji składają się:

— komunikacja: to, co firma komunikuje swojemu otoczeniu w sposób werbalny,

— wizualność: to, co firma komunikuje za pomocą symboli,

— behawioralność: działania wynikające z tożsamości ${ }^{7}$.

Analogicznie więc na tożsamość kraju składają się jego komunikacja z otoczeniem, symbolika oraz działania na arenie międzynarodowej.

Co ważne jednak, symbolika kraju obejmuje nie tylko tak oczywiste symbole, jak na przykład flaga, godło czy hymn, lecz także zwierzęta, rośliny oraz przedmioty kojarzone z danym krajem (na przykład kangur kojarzony z Australią). Ponadto zalicza się do niej logo narodowe (skonstruowane w celach promocyjnych) oraz pozostałe wyróżniki, które obejmują właśnie marki i produkty kojarzone z danym krajem (obok między innymi kultury, nazwy kraju czy wybitnych jednostek) ${ }^{8}$.

Tożsamość kraju jest więc pewnym zbiorem atrybutów komunikowanych przez kraj na zewnątrz, z kolei wizerunek jest sposobem, w jaki otoczenie je odbiera ${ }^{9}$.

Co ważne dla dalszych rozważań, istotną rolę w budowaniu wizerunków kraju odgrywają marki, które przez Simona Anholta określane są nawet mianem najważniejszych ich nośników ${ }^{10}$. Niewątpliwie jednak jednym z trudniejszych wyzwań stojących przed markami jest przełamywanie przez nie pewnych niepożądanych $\mathrm{z}$ ich punktu widzenia stereotypów i klisz, które pojawiają się w procesie transferu elementów wizerunku kraju na markę — w stosunku do zarówno odbiorców zagranicznych, jak i konsumentów pochodzących z tego samego kraju. Wyzwanie to jest tym trudniejsze dla tych branż, które nie są w sposób naturalny, poprzez głęboko utrwalone stereotypy, kojarzone z konkretnym miejscem pochodzenia, jak na przykład moda z Włochami, produkcja czekolady ze Szwajcarią czy Holandią, a tworzenie elektroniki — ze Stanami Zjednoczonymi, z Japonią czy Chinami.

Według Martina S. Rotha i Jeana B. Romeo istnieją cztery rodzaje relacji między wizerunkiem kraju a postrzeganiem kategorii produktów przez konsumentów. Pierwsza sytuacja występuje w przypadku, gdy postrzegane mocne strony krajów zgodne są z ważnymi dla konsumentów cechami produktów, które z nich

7 D. Tworzydło, Macierz celów wizerunkowych w procesie oceny efektów public relations, Rzeszów 2008, s. 13.

8 M. Daszkiewicz, P. Waniowski, [w:] Public relations - narzędzia przyszłości, red. T. Soliński, D. Tworzydło, Rzeszów 2007, s. 26-34.

9 M. Ryniejska-Kiełdanowicz, op. cit., s. 52-53.

10 S. Anholt, wypowiedź na konferencji Nation Branding Masterclass, London, 10 listopada 2006. Cyt. za: M. Hereźniak, Marka narodowa. Jak skutecznie budować wizerunek i reputacje kraju, Warszawa 2011, s. 70. 
pochodzą. Takie powiązanie jest najkorzystniejsze z punktu widzenia potencjalnego wykorzystywania przez markę informacji o kraju pochodzenia w swoich działaniach marketingowych. W drugim przypadku wizerunek kraju pochodzenia jest korzystny, jednak najważniejsze cechy kraju nie są jednocześnie cechami istotnymi dla danej grupy produktów. Trzeci przypadek to brak powiązań między najbardziej wyraźnymi elementami wizerunku kraju a ważnymi cechami produktów. Z czwartym przypadkiem mamy z kolei do czynienia, kiedy najwyraźniejsze cechy danego kraju nie są jego mocnymi stronami, ale jednocześnie nie są też ważne dla danej kategorii produktów. Zdaniem autorów znajomość powyższych powiązań istotna jest dla marek przy podejmowaniu decyzji o tym, czy w swoją komunikację marketingową wpleść informacje na temat kraju pochodzenia ${ }^{11}$.

I rzeczywiście, praktyka wskazuje na istnienie kilku grup marek w kontekście występowania efektu kraju pochodzenia w ich komunikacji marketingowej. Pierwszą grupą są te marki, które w swoją komunikację chętnie wplatają atrybuty marki narodowej (zapisane w oficjalnych dokumentach rządowych lub wynikające z pewnych skojarzeń z krajem). Przykładem mogą być między innymi Arla Foods (Dania), IKEA (Szwecja) czy Polskie Linie Lotnicze Lot oraz Orlen (Polska).

Drugą, dosyć liczną grupę tworzą marki, które zarówno wprost, jak i w sposób bardziej subtelny (na przykład poprzez odwołania do wspomnianych wyżej skojarzeń) nie komunikują kraju swojego pochodzenia. Może to być spowodowane albo przyjęciem pewnej określonej strategii komunikacyjnej, w której z różnorodnych powodów nie komunikuje się wyraźnie kraju swojego pochodzenia (na przykład pochodzenie z kraju obarczonego wieloma negatywnymi stereotypami) albo z braku wiedzy na temat roli współpracy i wzajemnych relacji marek i kraju $\mathrm{w}$ procesie brandingu narodowego.

Trzecią grupę stanowią te marki, które w swojej narracji marketingowej wskazują inny niż rzeczywisty kraj pochodzenia, stosując różnorodne metody komunikowania (na przykład obco brzmiącą nazwę, kolorystykę, odwołanie do określonych wartości czy symboli), jak na przykład pochodząca ze Stanów Zjednoczonych Neutrogena, która w swojej komunikacji odwołuje się do szeroko rozumianej norweskości.

Ostatnią grupą są marki, które oferują produkty i usługi nie kojarzone w sposób naturalny $\mathrm{z}$ krajem ich pochodzenia. $\mathrm{Z}$ marketingowego punktu widzenia znalazłyby się one w sytuacji niekorzystnej, jeśli zdecydowałyby się na komunikowanie swojego pochodzenia. Mimo to decydują się jednak podkreślać ten fakt i starają w sposób kreatywny uwypuklić i wpleść skojarzenia (często ukryte) z krajem w swoją komunikację marketingową lub przekuć cechy na pierwszy rzut oka nie-

11 M.S. Roth, J.B. Romeo, Matching Product Category and Country Image perceptions. A Framework for Managing Country-of-Origin Effects, „, Journal of International Business Studies” 23, 1992, nr 3, s. 487. 
korzystne w pozytywy. Do tej ostatniej grupy zdaje się należeć marka Elbrus, będąca przedmiotem zainteresowania niniejszego artykułu.

W kontekście problematyki komunikowania o kraju pochodzenia przez rosyjską markę komputera postawiono hipotezę, iż zgodność postrzegania kategorii produktów, jaką są komputery, oraz Rosji jako kraju pochodzenia sytuuje się na polach niekorzystnych, wskazanych przez Rotha i Romeo. Aby zweryfikować hipotezę, przeprowadzono badania pilotażowe na grupie 247 studentów, którym zadano następujące pytania badawcze:

— Który kraj najmocniej kojarzy się z kategorią produktów, jaką są komputery?

- Jakimi atrybutami pożądanymi z punktu widzenia konsumenta powinna charakteryzować się grupa produktów, jaką są komputery?

- Które skojarzenia tworzące jednocześnie wizerunek Rosji wśród respondentów są najbardziej wyraźne?

— Czy między atrybutami produktu a charakterystycznymi elementami wizerunku kraju zachodzi zgodność?

- Czy połączenie skojarzeniowe Rosja-komputer jest korzystne z punktu widzenia wspomnianej teorii Romeo i Rotha?

W tym miejscu wyjaśnienia wymaga dobór badanej grupy. Pytania o to, czy studenci mogą stanowić grupę reprezentatywną dla badań konsumenckich związanych z krajem pochodzenia, pojawiały się bowiem już we wczesnych latach dziewięćdziesiątych, gdy rodziły wiele spostrzeżeń i wątpliwości.

Jak wskazują Peter Veerlegh oraz Jan-Benedict Steenkamp, grupa respondentów, jaką są studenci, różni się od ogólnej grupy badanych pod względem socjodemograficznym oraz poprzez swoją homogeniczność. Po pierwsze, studenci są młodsi i lepiej wykształceni niż przeciętny konsument, a czynnik kraju pochodzenia ma zwykle mniejszy wpływ na młodszych respondentów. Po drugie, różnice między odpowiedziami w tej grupie będą mniej zróżnicowane niż w grupie przeciętnych respondentów. W opisanej sytuacji zachodzą więc dwa zjawiska z jednej strony oczekiwanie, iż respondenci zareagują słabiej na zjawisko kraju pochodzenia, a z drugiej — że wyniki w tej grupie będą silniejsze z uwagi na potencjalne mniejsze zróżnicowanie w odpowiedziach. Badania przeprowadzone przez autorów nie wskazały znaczących różnic we wpływie efektu kraju pochodzenia na grupę respondentów złożoną ze studentów i na respondentów stanowiących grupę reprezentatywną ${ }^{12}$, co pozwala na przełożenie wyników niniejszych badań na wnioski ogólne. Należy przy tym mieć na uwadze, iż są to jedynie badania pilotażowe wymagające dalszego pogłębienia.

Badania przeprowadzone metodą ankietową wykazały, że krajami najczęściej kojarzonymi z technologią komputerową są Stany Zjednoczone (87\% odpowiedzi) i Chiny (10\%). Zdecydowana większość badanych (98\%) jednocześnie udzieliła

12 P.W.J. Verlegh, J.-B. Steenkamp, A review and meta-analysis of country-of-origin research, „Journal of Economic Psychology” 20, 1999, s. 521-546. 
negatywnej odpowiedzi na pytanie, czy byliby zainteresowani zakupem komputera pochodzącego z Rosji. Tym samym wyniki ankiety potwierdziły potencjalne niekorzystne połączenie kategorii produktu i kraju.

Kolejne pytanie miało na celu sprawdzenie cech ważnych dla kategorii produktu, jakim jest komputer. Do najważniejszych cech (można było wskazać kilka) według respondentów należą szeroko rozumiane możliwości sprzętu, wskazujące jednocześnie na zaawansowanie technologiczne, jak na przykład procesor, karta graficzna, pamięć (87\%), niezawodność (84\%), solidność (64\%), cena (52\%), de$\operatorname{sign}(35 \%)$.

Odpowiedzi na kolejne pytanie miały z kolei wskazać najwyraźniejsze atrybuty Rosji, którymi okazały się (można było podać kilka odpowiedzi) mocarstwowość (89\%), militaryzm (67\%), kultura (65\%), a także dominacja lub dążenie do dominacji na arenie międzynarodowej (58\%).

Według Rotha i Romeo z punktu widzenia marki, która chce czerpać korzyści z pozytywnego postrzegania kraju pochodzenia, najkorzystniejsza sytuacja zachodzi, gdy następuje zgodność między mocnymi stronami kraju pochodzenia a cechami, które według odbiorców są najważniejsze dla danej grupy produktów. Biorąc pod uwagę powyższe odpowiedzi, można jednak stwierdzić, iż zaproponowane połączenie kategorii produktu i kraju sytuuje się na niekorzystnym polu zgodności z uwagi na brak zbieżności atrybutów.

$\mathrm{Z}$ marketingowego punktu widzenia podkreślanie kraju pochodzenia $\mathrm{w}$ takiej sytuacji wydaje się więc na pierwszy rzut oka nieuzasadnione, jednak w przypadku rosyjskiej marki Elbrus jest to przemyślana strategia. Jak bowiem podkreśla producent komputera, główną grupą docelową marki Elbrus są administracja państwowa i administracja samorządowa, instytuty badawcze i wojsko, a także przedsiębiorstwa o strategicznym przeznaczeniu ${ }^{13}$. Postrzeganie zbieżności skojarzenia Rosja-komputer w tej grupie, stanowiącej zbiór podmiotów strategicznych dla bezpieczeństwa kraju, jest więc odmienne niż w grupie reprezentatywnej lub istnieją oczekiwania, że takie właśnie będzie.

\section{Kontekst i metodologia analizy}

Marki mogą wykorzystywać różnorodne sposoby komunikowania o kraju swego pochodzenia, kształtując jednocześnie obraz danego kraju. Komunikacja ta może zachodzić na następujących płaszczyznach: nazwy marki lub linii produktów, kolorystyki i symboliki wykorzystywanej przez markę, wystroju punktów sprzedaży, informacji na produkcie wskazującej na kraj pochodzenia, obecności

13 A. Golański, Elbrus 401 PC wchodzi do masowej produkcji-Rosjanie maja już całkowicie własnego peceta, https://www.dobreprogramy.pl/elbrus-401-pc-wchodzi-do-masowej-produkcji-rosjanie-maja-juz-calkowicie-wlasnego-peceta,6628397896095873a?utm_source=popup_escape (dostęp: 28.05.2021). 
znanych osób kojarzonych z krajem, jak również nawiązań do języka, cech narodowych, stylu życia, tradycji i wartości narodowych, wzornictwa, kultury, wyglądu, krajobrazu oraz emocji, jakie wywołuje kraj. Komunikowanie kraju pochodzenia może również zachodzić dzięki sponsorowaniu wydarzeń związanych z krajem czy co-brandingowi z firmami kojarzonymi z krajem pochodzenia ${ }^{14}$.

W niniejszym opracowaniu skupiono się na analizie treści strony internetowej Moscow Centre of SPARC Technologies ${ }^{15}$, która stanowi swego rodzaju kompendium wiedzy na temat realizowanych przez instytucję projektów, w tym prac nad komputerem i procesorem Elbrus. Analiza została przeprowadzona w kilku etapach: sformułowanie pytań lub hipotez badawczych, określenie populacji i dobór próby, wybór jednostki analizy, ustalenie systemu kwantyfikacji, przeszkolenie kodujących lub przeprowadzenie badań pilotażowych oraz analiza danych i prezentacja wniosków ${ }^{16}$.

1. Pytania i hipotezy badawcze. Główną hipotezą badawczą jest założenie, że stosowana przez MCST komunikacja marketingowa marki ELBRUS celuje w kształtowanie pozytywnego wizerunku Rosji, aby utrwalić lub uzasadnić wybór tej konkretnej marki wśród wspomnianej wcześniej grupy odbiorców oraz aby stworzyć taki kontekst, w którym wybór rosyjskiego komputera wydałby się najbardziej korzystny z punktu widzenia potrzeb targetu. Tym samym komunikacja ta sytuuje połączenie komputer-Rosja w korzystnym polu skojarzeniowym Rotha i Romeo.

$\mathrm{Na}$ potrzeby realizacji zadania sformułowano więc następujące pytania badawcze:

— Które obszary funkcjonowania państwa podkreślane są w komunikowaniu o marce ELBRUS?

— Jaki obraz Rosji wyłania się z tych opisów?

2. Określenie populacji i dobór próby badawczej. Badana populacja obejmuje wszystkie teksty dotyczące marki ELBRUS, które pojawiły się na stronie internetowej MCST. Łącznie zebrano teksty składające się z 24 akapitów, stanowiące korpus badawczy analizy, poddany samodzielnemu tłumaczeniu.

3. Wybór jednostki analizy. Jednostką analizy są pojedyncze akapity poszczególnych tekstów dotyczących marki ELBRUS, a nie same teksty. Wstępna analiza wskazała bowiem, że w niektórych tekstach pojawiało się wiele wątków dotyczących Rosji, więc taki dobór jednostki analizy wydaje się mieć znaczący wpływ na rzetelność badań.

14 M. Hereźniak, op. cit., s. 83-86.

15 Moscow Center of Sparc Technologies (MCST) to rosyjska firma z branży IT założona w 1992 roku, stanowiąca obecnie podstawę działania Wydziału Informatyki i Inżynierii Komputerowej Moskiewskiego Instytutu Fizyki i Technologii.

16 R.D. Wimmer, J.R. Dominick, Mass media. Metody badań, przeł. T. Karłowicz, Kraków 2008, s. 216. 
4. Określenie systemu kwantyfikacji. Analiza ukierunkowana została na wskazanie obecności w tekstach tematów, które dotyczą Rosji i które mogłyby potencjalnie wpływać na kształtowanie jej wizerunku wśród odbiorców.

5. Przeszkolenie kodujących i przeprowadzenie badań pilotażowych. Badania zostały przeprowadzone samodzielnie i nie wymagały zaangażowania zespołu kodujących. Przeprowadzono badania pilotażowe, które miały na celu wstępne ustalenie kluczy kategoryzacyjnych i zweryfikowanie zasadności prowadzonego badania.

6. Analiza danych i prezentacja wniosków, którą zaprezentowano w dalszej części artykułu.

\section{Wizerunek Rosji w komunikacji MCST o marce ELBRUS - wyniki analizy}

Dalej przedstawiono wyniki analizy ilościowej i jakościowej, z podziałem na najbardziej charakterystyczne kategorie i podkategorie tematyczne. Struktura wątków pojawiających się w narracji marketingowej o marce Elbrus i tym samym kształtujących wizerunek Rosji została zdominowana przez te, które opisują to państwo jako uczestnika globalnej wojny cybernetycznej (58,3\%). Drugim charakterystycznym wątkiem było ukazanie Rosji jako kraju technologii komputerowej i zdolnych naukowców (33,3\%). Pozostałe akapity w żaden sposób nie odnosiły się do wątku Rosji (8,4\%).

\section{Rosja jako kraj technologii komputerowej i zdolnych naukowców}

Akapity, w których opisuje się Rosję jako kraj rozwiniętej technologii komputerowej, obejmują blisko 33,3\% wszystkich dotyczących marki ELBRUS. Warto przy tym zauważyć, iż to właśnie w byłym Związku Radzieckim w późnych latach siedemdziesiątych powstał pierwszy na świecie superskalarny komputer. To do tej historii MCST odwołuje się już na stronie głównej hasłem: „Elbrus to półwieczna historia rozwoju krajowej techniki komputerowej"17.

Zarysowanie wizerunku pożądanego Rosji jako kraju specjalistów w dziedzinie technologii komputerowej wydaje się istotne z uwagi na konieczność zapewnienia zgodności skojarzeniowej produktu i kraju pochodzenia, o której wspomniano wcześniej, a tym samym przekonania grupy docelowej co do przewagi rosyjskiej marki nad innymi, pochodzącymi z zagranicy, lub też uzasadnienia takiego wyboru.

W komunikacji marki Elbrus podkreśla się fakt pracy „doświadczonego zespołu" nad kilkoma generacjami rosyjskich komputerów, które poprzedziły powstanie nowoczesnej serii Elbrus ${ }^{18}$. Osiągnięcia zespołu opisane zostały jako „,zwracające

17 Oficjalna strona internetowa MCST, Strona główna, http://www.mcst.ru/ (dostęp: 15.05.2021).

18 Oficjalna strona internetowa MCST, Missija, http://www.mcst.ru/missija (dostęp: 15.05.2021). 
uwagę zagranicznych kolegów"19 i globalnej społeczności oraz jako powód nawiązania współpracy przez „wiele zagranicznych firm z rosyjskimi specjalistami" 20 .

Sama Rosja z kolei to kraj mający „ogromne możliwości w dziedzinie zaawansowanych technologii"21 oraz ,szybko posuwający się w drodze do informatyzacji wszystkich sfer życia społecznego"22. Niezawodność marki Elbrus pozwala z kolei na zastosowanie jej komputerów „do celów państwowych”, dzięki czemu kraj jest w stanie zapewnić bezpieczeństwo informacyjne i technologiczne ${ }^{23}$.

Warto w tym miejscu zauważyć, iż podkreślanie nowoczesności, zaawansowania technologicznego i niezawodności w komunikacji MCST o marce Elbrus wpisuje się w oczekiwania wspomnianych wcześniej respondentów badania pilotażowego w stosunku do komputera. Wplatanie wspomnianych wartości w komunikację marki ma więc zapewnić dopasowanie pary produkt-kraj do pola korzystnego z punktu widzenia skojarzeń.

\section{Rosja jako uczestnik globalnej wojny cybernetycznej}

W komunikacji o marce Elbrus najwięcej uwagi poświęcono międzynarodowym stosunkom Rosji z innymi mocarstwami w kontekście globalnego cyberbezpieczeństwa (58,3\%). Z tej narracji wyłania się obraz Rosji potężnej i skutecznie odpierającej ataki na jej strategiczne systemy informatyczne.

Interesujący jest przy tym kontekst dla narracji samej marki Elbrus, z którego wyłania się obraz świata jako pola cybernetycznej wojny: „eksperci szacują, że ponad 140 krajów na całym świecie opracowuje obecnie broń cybernetyczną"24, a „liczba operacji na frontach cyberprzestrzeni stale rośnie: każdego dnia na całym świecie przeprowadza się tysiące ataków" ${ }^{25}$, które bezpośrednio uderzają w infrastrukturę państw. Na stronie internetowej czytamy jednak wprost, iż rozwiązaniem mającym zapewnić Rosji bezpieczeństwo jest właśnie Elbrus.

Wśród opisów Rosji jako uczestnika globalnej wojny cybernetycznej można dostrzec dwa wątki - pierwszy dotyczy ataków hakerskich skierowanych na strategiczne instytucje państwowe (64\%), drugi zaś — istnienia mechanizmów szpiegujących w urządzeniach elektronicznych (36\%).

Jeżeli chodzi o pierwszy wątek, to narracja na stronie internetowej MCST prowadzona jest w sposób mający przedstawić bezradność światowych mocarstw w obliczu ataków hakerskich z zewnątrz, a jednocześnie ukazać Stany Zjedno-

19 Oficjalna strona internetowa MCST, Istorija predprijatija http://www.mcst.ru/istorija_predprijatija (dostęp: 15.05.2021).

20 Ibidem.

21 Oficjalna strona internetowa MCST, Missija...

22 Oficjalna strona internetowa MCST, Ugrozy bezopasnosti v globalnom kiberprostranstve, http://www.ineum.ru/ugrozy-bezopasnosti-v-globalnom-kiberprostranstve (dostęp: 15.05.2021).

23 Oficjalna strona internetowa MCST, Missija...

24 Oficjalna strona internetowa MCST, Ugrozy...

25 Ibidem. 
czone jako kraj, z którego najczęściej dochodzi do ataków na Rosję. Pozytywny wizerunek Rosji jako kraju skutecznie odpierającego ataki wspierany jest więc między innymi przez uwypuklenie słabych stron oraz zdyskredytowanie USA.

Przykładem uwypuklenia słabych stron jest opis ataku hakerskiego na Departament Stanu USA, Departament Gospodarki, Departament Obrony, Departament Energii, NASA oraz inne amerykańskie agencje rządowe, przeprowadzonego w 2007 roku. Atak ten, nazywany przez Amerykanów ,informacyjnym Pearl Harbor", jak również fakt, iż w 2010 roku skradziono z amerykańskich banków niemal 100 mln dolarów, były według tekstu głównymi przyczynami tego, że w 2010 roku Barack Obama uznał ochronę przed cyberatakami za priorytet państwa, a Kongres USA przeznaczył na ten cel 17 mld dolarów. MCST wspomina również, iż to właśnie Stany Zjednoczone jako pierwszy kraj na świecie uznało cyberprzestrzeń za „nowy obszar wojny, obok przestrzeni lądowej, morskiej i powietrznej” ${ }^{26}$. Fakt ten zdaje się również potwierdzać przytoczony przez MCST dwunasty akapit przyjętej w Lizbonie koncepcji dla Sojuszu Północnoatlantyckiego. W tym akapicie NATO uznaje cyberataki, za którymi ,mogą stać zagraniczne siły zbrojne, agencje wywiadowcze, przestępczość zorganizowana oraz grupy terrorystyczne i ekstremistyczne”, za „zagrażające dobrobytowi, bezpieczeństwu oraz stabilności narodowej i euroatlantyckiej" 27 . Bez wątpienia więc zagrożenie atakami cybernetycznymi ukazane jest przez MCST jako problem globalny.

Strona internetowa MCST służy jednak nie tylko uwypukleniu słabych stron Stanów Zjednoczonych, lecz także zdyskredytowaniu tego kraju, co zauważalne jest w niemal 57\% akapitów poświęconych tematyce Rosji jako uczestnika globalnej wojny cybernetycznej. Narracja o marce Elbrus ukazuje USA jako kraj przodujący na świecie „pod względem liczby wychodzących ataków hakerskich”28. Jako przykład takich działań hakerskich MCST opisuje atak wirusa komputerowego Stuxnet na irańskie obiekty jądrowe w 2011 roku. Na stronie internetowej czytamy wprost, iż to Stany Zjednoczone i Izrael były autorami i organizatorami ataku, którego celem były „próba sparaliżowania irańskiego programu nuklearnego bez użycia siły wojskowej oraz wywierania presji psychologicznej na Iran"29.

Pozytywny wizerunek Rosji kreowany jest poprzez nie tylko dyskredytowanie konkurentów i opisywanie ich słabych stron, lecz także przemilczenie przykładów ataków na Rosję. Mówi się tylko o tym, iż Rosja „zajmuje trzecie miejsce na świecie pod względem liczby prób ataków na komputery", przy czym kluczowe znaczenie ma tu użycie słowa „próba”, które nie przesądza o skuteczności takich działań. Roczne straty spowodowane tymi działaniami szacuje się z kolei na mniej

\footnotetext{
26 Ibidem.

27 Ibidem.

28 Ibidem.

29 Ibidem.
} 
więcej 4 mld dolarów ${ }^{30}$, co w porównaniu do wspomnianych wcześniej strat Stanów Zjednoczonych wydaje się kwotą niewielką. Przemilczany w tekście został również fakt, iż według wspomnianego wcześniej raportu Rosja również znajduje się wśród państw (obok USA, Chin, Brazylii i Włoch), z których najczęściej dochodzi do ataków cybernetycznych na inne kraje ${ }^{31}$.

Drugim wątkiem, który pojawia się w niemal 64\% akapitów dotyczących uczestnictwa Rosji w globalnej wojnie cybernetycznej, jest potencjalna możliwość istnienia oprogramowania szpiegującego w „niemal każdym”32 urządzeniu elektronicznym służącym do komunikacji, a które to oprogramowanie może być wbudowane w nie już na etapie produkcji. Luki te, nazwane przez MCST „owocami doskonałości technologicznej"33 , również zostały przedstawione jako ogromne wyzwanie dla bezpieczeństwa Rosji. Wyzwanie tym większe, że „dominujące obecnie na świecie technologie komputerowe są opracowywane przez wiodacce amerykańskie korporacje" 34 .

W wątku tym Rosja znów osadzona została więc w kontekście globalnej walki o informacje, w której to walce głównym jej przeciwnikiem są Stany Zjednoczone. Zostały one ponadto opisane jako kraj, który traktuje możliwość instalowania oprogramowania szpiegującego w produkowanych przez siebie urządzeniach jako „czynnik zapewniający strategiczną przewagę, a w razie potrzeby — wywieranie presji politycznej, gospodarczej i wojskowej na inne kraje" 35 .

Narracja marketingowa prowadzona przez MCST w tym wątku skonstruowana jest więc na bazie kontrastu między opisem niekorzystnego kontekstu międzynarodowego, w jakim obecnie znajduje się Rosja, wraz z niebezpieczeństwami płynącymi ze strony innych mocarstw, a ideą marki Elbrus jako głównego narzędzia we wspomnianej cyberwalce. I tak na stronie internetowej czytamy na przykład o wysiłkach rosyjskich przywódców, którzy już od połowy lat dziewięćdziesiątych podejmowali działania ukierunkowane na redukcję zagrożeń wynikających z możliwości instalowania oprogramowania szpiegującego w urządzeniach. Ukazani zostali oni w narracji marketingowej jako świadomi zagrożeń i ,podejmujący poważne kroki"36 ukierunkowane na rozwój rosyjskiej technologii komputerowej. „Znaczącym rezultatem” ich działań jest między innymi stworzenie rosyjskiego mikroprocesora z wydajnością ,porównywalną z produktami wiodących firm

\footnotetext{
30 Ibidem.

31 Ibidem.

32 Ibidem.

33 Ibidem.

34 Ibidem.

35 Ibidem.

36 Ibidem.
} 
zagranicznych"37. Co więcej, mikroprocesor Elbrus według MCST jest doskonałym zabezpieczeniem przed wirusami komputerowymi ${ }^{38}$.

\section{Zakończenie}

Analiza korpusu badawczego wykazała, iż narracja marketingowa MCST o marce Elbrus niemal całkowicie zdominowana jest przez opisy tworzące wizerunek Rosji. Dwa główne wątki dotyczące tego państwa - jako kraju nowoczesnych technologii i specjalistów w branży IT oraz kraju biorącego udział w globalnej wojnie cybernetycznej — znajdziemy bowiem w 91,6\% wszystkich akapitów poświęconych brandowi.

Obraz Rosji jako kraju specjalistów w dziedzinie technologii komputerowej wydaje się przy tym odgrywać nie tylko rolę pewnego dodatkowego tła dla produktu. Wydaje się, że podkreślanie tych atrybutów w narracji marketingowej o marce Elbrus ma przede wszystkim na celu zapewnienie zgodności skojarzeniowej produktu i kraju pochodzenia zgodnie z teorią Romeo i Rotha, a tym samym przekonanie (lub utwierdzenie w przekonaniu) grupy docelowej o przewadze rosyjskiej marki nad innymi markami, pochodzącymi z zagranicy. Podkreślanie nowoczesności, zaawansowania technologicznego i niezawodności w komunikacji MCST o marce Elbrus wpisuje się bowiem w oczekiwania respondentów z przeprowadzonego przez autorkę niniejszego artykułu badania pilotażowego w stosunku do komputera.

Interesujący jest również kontekst narracji samej marki Elbrus, z którego wyłania się obraz świata jako pola cybernetycznej wojny. Kontekst, w którym nie tylko podkreśla się mocne strony Rosji jako na przykład kraju skutecznie odpierającego ataki hakerów, lecz także uwypukla słabe strony innych mocarstw czy nawet je dyskredytuje. Pozytywny wizerunek Rosji w narracji marketingowej o marce Elbrus kreowany jest ponadto przez przemilczenie faktów, które mogłyby mieć negatywny wpływ na postrzeganie tego kraju, czego przykładem może być celowe użycie słowa ,próba” w kontekście liczby hakerskich ataków na ten kraj z zagranicy. Wizerunek Rosji stanowi więc sumę nie tylko elementów, o których wspomina się w narracji, lecz także tych, które są przemilczane.

Narracja marketingowa o marce Elbrus zdominowana przez opisy Rosji tworzy więc swoisty kontekst uzasadniający atrakcyjność samego produktu zgodnie z teorią Romeo i Rotha. W przypadku narracji marketingowej o marce Elbrus zauważalne jest oddziaływanie zarówno wizerunku kraju na wizerunek marki (efekt halo), jak i wizerunku marki na wizerunek kraju (efekt sumaryczny). Elbrus bowiem,

\section{Ibidem.}

38 Oficjalna strona internetowa MCST, Zashhishennoe ispolenenie program na baze apparatoj i sistemoj podderzhki arkhitektury elbrus, http://www.mcst.ru/zashhishhennoe-ispolnenie-programm-na-baze-apparatnoj-i-sistemnoj-podderzhki-arkhitektury-elbrus (dostęp: 15.05.2021). 
jako owoc „półwiecznej historii rozwoju krajowej techniki komputerowej”39, gwarantujący bezpieczeństwo strategicznych gałęzi rosyjskiej gospodarki, gdyż „skutecznie zabezpieczający przez wirusami komputerowymi’40, wzmacnia wizerunek Rosji jako kraju nowoczesnego, kraju zaawansowanej technologii.

Oba zjawiska występujące w narracji o marce Elbrus odgrywają więc w procesie brandingu narodowego rolę wzajemnie wspierającą, co świadczy o wysokiej świadomości decydentów nie tylko co do ostatecznego rezultatu działań wizerunkowych Rosji, lecz także co do niezwykle istotnej roli, jaką w procesie brandingu narodowego odgrywają marki narodowe, mogące być jednymi z najważniejszych nośników wizerunku kraju, z którego pochodzą.

\section{Bibliografia}

\section{Monografie i rozdziały}

Anholt S., Sprawiedliwość marek. Jak branding miejsc i produktów może uczynić kraj bogatym, dumnym i pewnym siebie, przeł. M.A. Boruc, M. Hereźniak, Warszawa 2006.

Anholt S., Tożsamość konkurencyjna. Nowe spojrzenie na markę, przeł. Instytut Marki Polskiej, Warszawa 2007.

Daszkiewicz M., Waniowski P., [w:] Public relations - narzędzia przyszłości, red. T. Soliński, D. Tworzydło, Rzeszów 2007.

Hereźniak M., Marka narodowa. Jak skutecznie budować wizerunek i reputację kraju, Warszawa 2011.

Ryniejska-Kiełdanowicz M., Public relations Polski w okresie kandydowania do Unii Europejskiej, Wrocław 2007.

Tworzydło D., Macierz celów wizerunkowych w procesie oceny efektów public relations, Rzeszów 2008.

Wimmer R.D., Dominick J.R., Mass media. Metody badań, przeł. T. Karłowicz, Kraków 2008.

\section{Artykuły naukowe}

Kotler Ph., D. Gertner, Country as a brand, product, and beyond: A place marketing and brand management perspective, „Journal of Brand Management” 9, 2002, nr 4-5.

Roth M.S., Romeo J.B., Matching Product Category and Country Image perceptions: A Framework for Managing Country-of-Origin Effects, „Journal of International Business Studies” 23, 1992, nr 3.

Verlegh P.W.J., Steenkamp J.-B., A review and meta-analysis of country-of-origin research, „Journal of Economic Psychology" 20, 1999.

\section{Źródła internetowe}

Golański A., Elbrus 401 PC wchodzi do masowej produkcji - Rosjanie maja już całkowicie własnego peceta, https://www.dobreprogramy.pl/elbrus-401-pc-wchodzi-do-masowej-produkcji-rosjanie-maja-juz-calkowicie-wlasnego-peceta,6628397896095873a?utm_source=popup_escape.

Oficjalna strona internetowa Moscow Centre of Sparc Technologies, http://www.mcst.ru/.

39 Oficjalna strona internetowa MCST, Strona główna...

40 Oficjalna strona internetowa MCST, Zashhishennoe... 